\title{
Plasma profile of progesterone, estradiol-17 $\beta$ and some blood biochemical attributes during different gestation periods in Iraqi female dromedary camels (Camelus dromedarius)
}

\author{
Talal Anwer Abdulkareem ${ }^{1 *}$, Hani Muneeb Al-Rawi ${ }^{2}$, Yassen Taha Abdul-Rahaman² \\ ${ }^{1}$ Department of Animal Resource, College of Agriculture, University of Baghdad, Iraq; ${ }^{2}$ College of Veterinary Medicine, University of Anbar, Iraq
}

\section{A B S T R A C T}

\begin{abstract}
This study was conducted to demonstrate the plasma profile of progesterone, estradiol- $17 \beta$ and some blood biochemical attributes (glucose, cholesterol concentrations and alkaline phosphates activity) of Iraqi female dromedary camels (Camelus dromedarius) during different gestation periods. This experiment included 5 multiparous, non-lactating Iraqi one-humped female camels (Camelus dromedarius) of 7- 8 years old. Blood was collected from female camels at days 20, 30, 40, 50, 60, 90, 120, 150 and 180 post-mating (PM). The plasma progesterone concentrations did not significantly differ among days $20-120$ PM. Greater (P $\leq 0.05)$ progesterone concentrations were observed at days 150 and 180 PM as compared with days.20, 30 and 40 PM. No remarkable alterations in plasma estradiol-17 $\beta$ concentrations were seen among different gestation periods. Non- significant variations were detected in plasma glucose concentrations during the entire gestation periods studied (day 20-60 PM). Higher $(p<0.05$ ) cholesterol concentrations were observed at days $20(9.86 \pm 0.59 \mathrm{mg} / \mathrm{dl})$ and $30(8.84 \pm 0.32 \mathrm{mg} / \mathrm{dl})$ in comparison with their counterpart values at days $50(7.06 \pm 0.1 \mathrm{mg} / \mathrm{dl})$ and $60(6.29 \pm 0.26 \mathrm{mg} / \mathrm{dl})$ PM. The overall mean of plasma alkaline phosphatase activity did not alter during the whole study period. In conclusion, the pronounced changes during gestation period in dromedary camels can be detected through sex hormones and plasma cholesterol concentrations.
\end{abstract}

Keywords: Progesterone; Estradiol-17 $\beta$; Blood attributes; Dromedary camel

\section{INTRODUCTION}

Blood is an important index for several metabolic processes in the body which may in one animal species vary due to age, sex, physiological conditions and environmental factors (Ayoub et al., 2003). The physiological conditions had more influence biochemical and hormonal rather than hematological indices in camel raised under traditional conditions (Muhammad et al., 2011). The pattern of secretion of progesterone and estradiol-17 $\beta$ has been well-documented in cattle, buffalo, sheep, goat, mare and pig but is less well understood and limited in the camel (Ayoub et al., 2003). Camel is different in that the ovulation is an induced rather than the spontaneous type in most species (Sumar, 2000). Rhythmic secretion of these sex steroids has a definite correlation with sexual behavior and receptivity of the male by females in other species of livestock. In camelids, the periods of estrous and non-receptivity do not necessarily coincide with ovarian status and levels of estradiol-17 $\beta$ and progesterone (Quzy et al., 2013).

The maternal glucose regulates the expression of placental lactogen (PL) receptors in fetal liver. This PL binding may contribute to the increase in fetal insulin and insulin-like growth factor-1 (IGF-1). PL, insulin and IGF-1 increase glucose and amino acid transport in preadipocytes and fetal myoblasts and stimulates glycogen synthesis in fetal hepatocytes, and thereby enhance fetal growth and development (Freemark et al., 1992). The cholesterol is a precursor of the most steroid hormones, including progesterone in most ruminant species including camels. High levels of progesterone during pregnancy are always accompanied with decreasing cholesterol concentrations

\footnotetext{
${ }^{*}$ Corresponding author:

Talal Anwer Abdulkaeem, Department of Animal Resource, College of Agriculture, University of Baghdad, Iraq.
}

Email: talal200320032000@yahoo.com, +9647801697514

Received: 17 April 2015;

Revised: 27 May 2015;

Accepted: 29 May 2015;

Published Online: 29 May 2015 
as a result of cholesterol catabolism to progesterone via cholesterol esterase. The hyper-cholesterolemia during pregnancy indicated by approximately $50 \%$ increase over the no-pregnant level has been known to influence fetus growth and particularly endocrine function (Sahukar et al., 1986). The alkaline phosphatase normally produced by syncytiotrophoblast cells of placenta and may be involved in migration of primordial germ cell in developing fetus (Heller and Joshi, 2006). In pregnant cows, increases in alkaline phosphatase may be up 4 times normal during mid-pregnancy, playing an important role in fetus musculature via transfer of phosphate (Fernandez and Kidney, 2007).

A slight decrease in plasma progesterone levels occurs over the 70-80 days of pregnancy followed by a rapid drop in values of $<1 \mathrm{ng} / \mathrm{ml}$ on day before, or the day of parturition (Elias et al., 1984, Skidmore et al., 1996a, Al-Eknah, 2009 and Skidmore, 2011). In another study (Ayoub et al., 2003), progesterone levels ranged from 0.29 to $2.87,1.40$ to 6.45 and 0.50 to $1.80 \mathrm{ng} / \mathrm{ml}$ in a non-pregnant, pregnant and in camels during estrous cycle respectively. Moreover, Hegazy et al (2004) found that progesterone concentration increased during pregnancy up to $6.45 \mathrm{ng} / \mathrm{ml}$, then it decreased to reach 1.19 to $2.47 \mathrm{ng} / \mathrm{ml}$ after parturition and between 0.0 and $4.7 \mathrm{ng} / \mathrm{ml}$, non-pregnant. In Nigeria, Muhammad et al (2011) reported plasma progesterone concentration of pregnant $4.23 \mathrm{ng} / \mathrm{ml}$ and non- pregnant $1.39 \mathrm{ng} / \mathrm{ml}$. Bakheit et al (2012) reported that progesterone concentration increased significantly $(\mathrm{p} \leq 0.05)$ during the early months of pregnancy to a value above $2 \mathrm{ng} / \mathrm{ml}$ blood. Quzy et al (2013) observed camels evidencing serum progesterone profiles above 2.0 and $3.0 \mathrm{ng} / \mathrm{ml}$ at 20 and 30 days of mating should be considered pregnant. Estrogen in camels has been reported to be highly variable and seemingly impossible or difficult to interpret (Zhao and Chen, 1995). It is speculated but not definitely confirmed that for camelids, as for other species, the concentration of estradiol-17 $\beta$ is critical for triggering the ovulatory surge of LH (Tibary and Anouassi, 1997).

Trace elements, minerals and enzymes have been described in the blood of female camels during different reproductive statuses including the estrous cycle (Mohamed, 2004), pregnancy (Skidmore et al., 1996a and Zhao et al., 1998) and postpartum period (Eltohamy et al., 1986 and Agarwal et al., 1992). Management practices and nutrition schedule may alters these values (Bhakat et al., 2012). Furthermore, no previous study was undertaken to describe the sex hormones and blood profiles of Iraqi female dromedary camels during different gestation periods. This prompted us to examine the profiles of plasma progesterone, estradiol-17 $\beta$, glucose and cholesterol concentrations as well as alkaline phosphatase activity during different gestation periods of Iraqi female dromedary camels.

\section{MATERIALS AND METHODS}

\section{Animals}

This study was conducted at the Animal Farm, College of Veterinary Medicine, University of Anbar during the period from $1 / 8 / 2012$ until 1/8/2013. This experiment included 5 multiparous, non-lactating Iraqi one-humped female camels (Camelus dromedarius) of 7- 8 years old. Animals were daily fed per head of $4 \mathrm{~kg}$ green roughages (alfalfa, barley and sorghum), $10 \mathrm{~kg}$ of alfalfa hay and $0.5 \mathrm{~kg}$ of barley grains (Farid, 1995). Water and mineral blocks were available ad libitum. Camels kept in semi-closed fenced pens with appropriate area for moving easily. Estrus, and mating signs were monitored constantly for each animal. The pregnancy were detected by ultrasonography and confirmed by rectal palpation. Females were naturally mated with fertile males.

\section{Blood sampling and assay}

Blood samples per female taken via jugular venipuncture at days 20, 30, 40, 50 and $60 \mathrm{PM}$ for progesterone, estradiol $17^{\beta}$ and some blood biochemistry (glucose, cholesterol concentrations and alkaline phosphatase activity) and continued to 90, 120, 150 and $180 \mathrm{PM}$ for progesterone and estradiol-17 $\beta$ concentrations. The blood sample immediately $(10 \mathrm{ml})$ were collected via heparinized vacutainer tubes, and plasma were harvested following centrifugation of the samples (3000 RPM for 15 minutes) and stored under $-20^{\circ} \mathrm{C}$ until assay. Radioimmunoassay (RIA) used to measure the plasma progesterone concentration ( $\mathrm{ng} / \mathrm{ml}$ ) and plasma estradiol$17 \beta(\mathrm{pg} / \mathrm{ml})$. The kits provided by Immunotech, A Beckman Coulter Company, de Lattre de Tassigny, Marseille, France. The assay carried out at Al-Nadhaer Clinical Laboratory, Baghdad. Inter- and intra-assay coefficients of variation $(\mathrm{CV} \%)$ were $7.2 \%$ and $6.5 \%$ respectively. Glucose (Trinder, 1969) and cholesterol (Allain et al., 1974) concentrations were quantitatively determined using the kit provided by Agappe Diagnostice Company, Switzerland. Alkaline phosphatase activity was assessed using Kind and King (1954) method. The kit was provided by Biomerieux Company, France. The assay was undertaken at Al-Nazil Clinical Laboratory, Falloja- Anbar.

\section{Statistical analyses}

Statistical computations were performed using General Linear Model (GLM) procedure in the SAS program (SAS, 2012) to examine the influence of gestation periods on plasma progesterone, estradiol- $17 \beta$ and other blood biochemical parameters. The statistical model for analysis of variance (ANOVA) was: 
$Y i j=\mu+P i+e i j$

Where:

Yij $=$ dependent variable (plasma progesterone, estradiol$17 \beta$, glucose and cholesterol concentrations as well as alkaline phosphatase activity).

$\mu=$ overall mean.

$\mathrm{Pi}=$ effect of gestation period $(\mathrm{P}=$ Days 20, 30, 40, 50, 60 PM for plasma glucose, cholesterol and alkaline phosphatase and continued until, 90, 120,150 and 180 PM for plasma progesterone, estradiol-17 $\beta$ ).

eij $=$ error term

Differences among means were computed using the Duncan multiple range test (Duncan, 1955).

\section{RESULTS}

\section{Plasma progesterone concentrations}

The overall mean of plasma progesterone concentration was significantly $(\mathrm{p} \leq 0.05)$ different along the gestation. The peripheral level did not significantly differ among days 20-120 PM, however, it tended to be lower at day 20PM (3.97 $\pm 1.38 \mathrm{ng} / \mathrm{ml})$ and higher at day $90 \mathrm{PM}(7.81 \pm 0.50 \mathrm{ng} / \mathrm{ml})$. Greater $(\mathrm{p} \leq 0.05)$ progesterone concentrations were observed at days $150(10.23 \pm 3.67 \mathrm{ng} / \mathrm{ml})$ and $180(11.90 \pm 1.93 \mathrm{ng} / \mathrm{ml})$ PM (Fig. 1 and Table 1).

\section{Plasma estradiol-17 $\beta$ concentrations}

No remarkable alterations in plasma estradiol-17 $\beta$ concentrations were seen among different gestation periods. However, it tended to be numerically greater at days $30(45.80 \pm 7.74 \mathrm{pg} / \mathrm{ml})$ and $120(43.83 \pm$ $2.91 \mathrm{pg} / \mathrm{ml}$ ) PM as compared with their concentrations at days $60(33.60 \pm 6.26 \mathrm{pg} / \mathrm{ml}), 20(34.50 \pm 2.25 \mathrm{pg} / \mathrm{ml})$ and 180 (34.50 \pm 3.48 pg/ml) PM (Fig. 2 and Table 1).

\section{Plasma glucose concentrations}

Consistent with estradiol-17 $\beta$, non- significant variations were detected in plasma glucose concentrations during the entire gestation periods (day 20-60 PM). Its concentration ranged from $110.60 \pm 5.93 \mathrm{mg} / \mathrm{dl}$ at day $60 \mathrm{PM}$ to $135.00 \pm 5.86 \mathrm{mg} / \mathrm{dl}$ at day $20 \mathrm{PM}$ (Fig. 3 and Table 1).

\section{Plasma cholesterol concentrations}

Significant differences were noticed in plasma cholesterol concentrations over the study periods. Higher $(\mathrm{p} \leq 0.05)$ concentrations were observed at days 20 (9.86 \pm $0.59 \mathrm{mg} / \mathrm{dl})$ and $30(8.84 \pm 0.32 \mathrm{mg} / \mathrm{dl}) \mathrm{PM}$ in comparison with their counterpart values at days $50(7.06 \pm 0.1 \mathrm{mg} / \mathrm{dl})$ and $60(6.29 \pm 0.26 \mathrm{mg} / \mathrm{dl}) \mathrm{PM}$. However, the differences in cholesterol concentrations between days 20 and 30, 30 and 40, 40 and 50 as well as 50 and 60 PM lacked significance (Fig. 4 and Table 1).

\section{Plasma alkaline phosphatase activity}

The overall mean of plasma alkaline phosphatase activity did not change during the study period. However, it tended to be numerically greater $(+43.9 \%)$ at day 60 PM (44.60

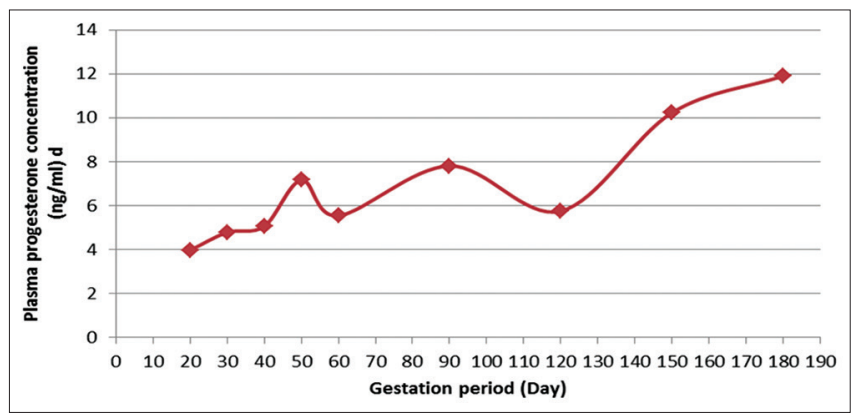

Fig 1. Plasma progesterone concentrations $(\mathrm{ng} / \mathrm{ml})$ of Iraqi female camels during different gestation periods.

\begin{tabular}{|c|c|c|c|c|c|}
\hline $\begin{array}{l}\text { Gestation period } \\
\text { (days post-mating) }\end{array}$ & $\begin{array}{l}\text { Plasma progesterone } \\
\text { concentration }(\mathrm{ng} / \mathrm{ml})\end{array}$ & $\begin{array}{l}\text { Plasma estradiol-17 } \\
\text { concentration }(\mathrm{pg} / \mathrm{ml})\end{array}$ & $\begin{array}{c}\text { Plasma glucose } \\
\text { concentration (mg/dl) }\end{array}$ & $\begin{array}{l}\text { Plasma cholesterol } \\
\text { concentration }(\mathrm{mg} / \mathrm{dl})\end{array}$ & $\begin{array}{c}\text { Plasma alkaline } \\
\text { phosphatase activity (U/L) }\end{array}$ \\
\hline 20 & $3.97 \pm 1.38 b$ & $34.50 \pm 2.25 a$ & $135.00 \pm 5.86 a$ & $9.86 \pm 0.59 a$ & $32.00 \pm 5.36 a$ \\
\hline 30 & $4.78 \pm 1.55 b$ & $45.80 \pm 7.74 a$ & $131.80 \pm 5.39 a$ & $8.84 \pm 0.32 a b$ & $31.00 \pm 4.52 a$ \\
\hline 40 & $5.06 \pm 1.85 b$ & $38.80 \pm 5.86 a$ & $122.80 \pm 4.09 a$ & $7.77 \pm 0.68 b c$ & $34.80 \pm 6.52 a$ \\
\hline 50 & $7.16 \pm 2.09 a b$ & $36.20 \pm 2.71 a$ & $113.60 \pm 13.79 a$ & $7.06 \pm 0.1 \mathrm{~cd}$ & $37.00 \pm 1.58 a$ \\
\hline 60 & $5.54 \pm 1.88 a b$ & $33.60 \pm 6.26 a$ & $110.60 \pm 5.93 a$ & $6.29 \pm 0.26 d$ & $44.60 \pm 13.36 a$ \\
\hline 90 & $7.81 \pm 0.50 a b$ & $36.67 \pm 4.36 a$ & - & - & - \\
\hline 120 & $5.75 \pm 0.67 a b$ & $43.83 \pm 2.91 a$ & - & - & - \\
\hline 150 & $10.23 \pm 3.67 a$ & $41.67 \pm 2.04 a$ & - & - & - \\
\hline 180 & $11.90 \pm 1.93 a$ & $34.50 \pm 3.48 a$ & - & - & - \\
\hline Level of significance & * & NS & NS & * & NS \\
\hline
\end{tabular}

NS: Not significant, ${ }^{*}: \mathrm{P} \leq 0.05$. Means with different superscripts within each column differ significantly $(\mathrm{P} \leq 0.05)$ 
$\pm 13.36 \mathrm{U} / \mathrm{L})$ as compared with its activity at day $30 \mathrm{PM}$ (31.00 $\pm 4.52 \mathrm{U} / \mathrm{L})$ (Fig. 5 and Table 1).

\section{DISCUSSION}

These results of steadily and non-significantly increasing plasma progesterone from day $20 \mathrm{PM}$ to day 120 of gestation were consistent with those obtained by Skidmore et al (1996a) who found that the mean serum concentrations of female dromedary camels during the first 90-100 days of gestation were 3-5 $\mathrm{ng} / \mathrm{ml}$. Our current plasma progesterone concentrations were increased from day 150 to 180 of gestation. In dromedary and Bactrian camels, the corpus luteum of pregnancy

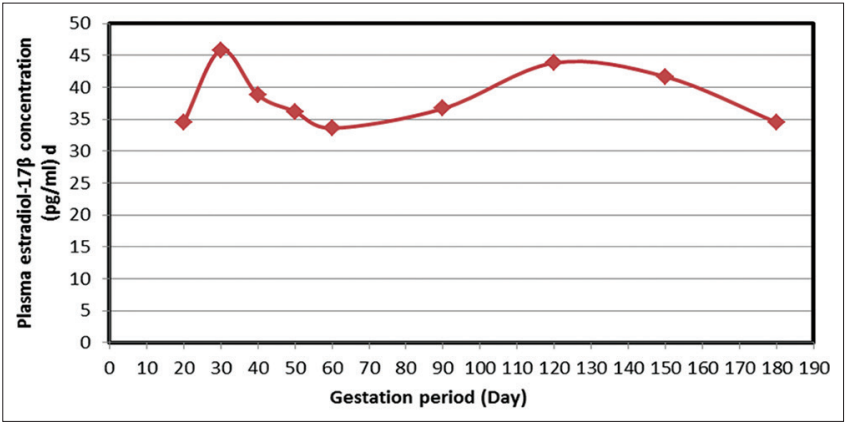

Fig 2. Plasma estradiol-17 $\beta$ concentrations ( $\mathrm{ng} / \mathrm{ml}$ ) of Iraqi female camels during different gestation periods.

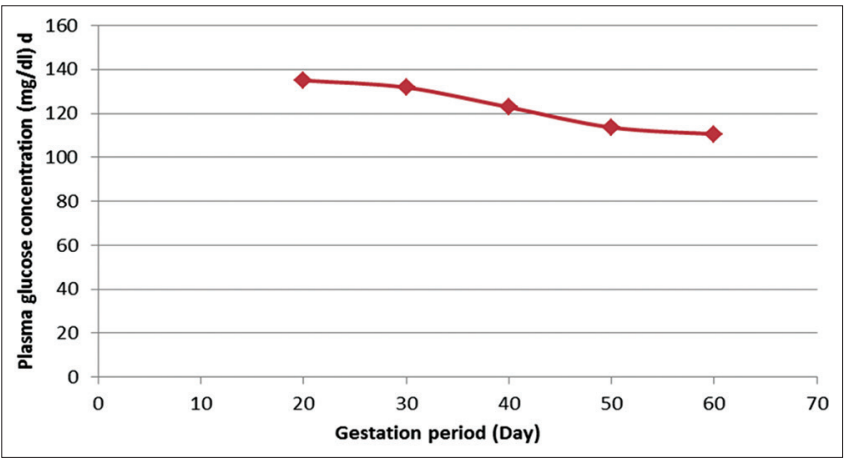

Fig 3. Plasma glucose concentrations ( $\mathrm{mg} / \mathrm{dl}$ ) of Iraqi female camels during different gestation periods.

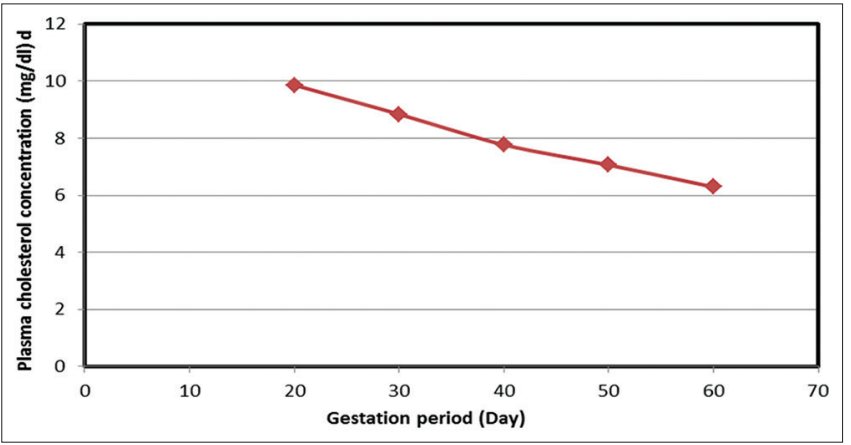

Fig 4. Plasma cholesterol concentrations ( $\mathrm{mg} / \mathrm{dl}$ ) of Iraqi female camels during different gestation periods. persists throughout the gestation periods (El-Wishy et al., 1981) and thus it is assumed that ovarian progesterone is mandatory throughout gestation in this species (AlEknah et al., 1997). These authors observed that removal of ovaries containing corpora lutea at 10-11 months of pregnancy followed by abortion or premature birth. This indicates that the ovary is the major source of progesterone in pregnant camels. This is consistent with the finding of llama, which is a member of Camelidae family (Smith et al., 1994). Following mating, at least one corpus luteum is formed secreting significant amount of progesterone (Al-Bisher, 1998). Moreover, plasma progesterone concentration could be regards as a good method for early pregnancy detection in female dromedary camels (Abdulkareem et al., 2015a).

The current non-significant increasing in estradiol-17 $\beta$ concentrations at days 30 and 120 PM were higher than those demonstrated by Deen et al (2007) at day 30 PM $(0.69-8.24 \mathrm{pg} / \mathrm{ml})$. The present data were lower than values reported by Skidmore et al(1996b) at day 50 PM $(100 \mathrm{pg} / \mathrm{ml})$ in dromedary camels. On the other hand, our results were consistent with Elias et al (1984) who measured estradiol$17 \beta$ concentrations at monthly intervals in pregnant camels and found that the concentrations remained constant at $50-100 \mathrm{pg} / \mathrm{ml}$ during the first 10 months of gestation before rising to a peak during the twelfth month. This dissimilarity among studies may attributed to the type of estradiol$17 \beta$ assay kit (inter-assay, intra-assay and sensitivity) and methods (ELISA or RIA) used as well as management practices. It was observed that improved feeding regime $(13 \%$ crude protein and 2.9 Mcal metabolizable energy) increased estradiol-17 $\beta$ concentrations in female dromedary camels as compared with those fed traditional feeding (Al-Saiady et al., 2012). It was noticed that estradiol-17 $\beta$ level in pregnant camels is a fetoplacental in origin (Ayoub et al., 2003). Elias et al (1984) found very high concentrations of estradiol-17 $\beta$ (241-390 pg/ $\mathrm{ml}$ ) in the allantoic fluids of camels at birth. In addition, the increased estrogen production of estrogens coincides with an increase in fetal growth and a substantial increase in fetal fluid volume observed between 9 and 12.5 months of pregnancy in dromedary camels (El-Wishy et al., 1981). This also suggests that placental estrogens are important for fetal growth in camels. Moreover, definitive evidence for strong aromatase activity with the synthesis of considerable quantities of estrogens was obtained at all camel pregnancy stages when conceptus tissues incubated with $[3 \mathrm{H}]$ androstenedione. Biopsies of endometrial tissue recovered from pregnant and non-pregnant camels showed great ability to conjugate both estradiol-17 $\beta$ and estrone when incubated with tritium-labeled forms of these two hormones (Skidmore et al., 1994). 
The steady non-significant variations pattern of plasma glucose concentrations during early gestation period may indicate lack of changes in the absolute rate of maternal gluconeogenesis and glycolysis. The maternal glucose regulates the expression of placental lactogen (PL) receptors in fetal liver. This PL binding may contribute to the increase in fetal insulin and insulin-like growth factor-1 (IGF-1). PL, insulin and IGF-1 increase glucose and amino acid transport in preadipocytes and fetal myoblasts and stimulates glycogen synthesis in fetal hepatocytes, and thereby enhance fetal growth and development (Freemark et al., 1992). A similar trend of glucose concentration that noticed in embryonic fluids and fetal serum collected from the buffalo females during three different gestation periods (Abdulkareem et al., 2012) may confirm this notion. Reducing insulin secretion during pregnancy is proposed to be beneficial to fetal wellbeing, through the creation of an environment which supports minimizing peripheral glucose utilization and maximizing glucose extraction of the gravid uterus (Connolly et al., 2000). It is noteworthy, the present plasma glucose concentrations $(110-135 \mathrm{mg} / \mathrm{dl})$ were relatively within the normal reference values $(79-115 \mathrm{mg} / \mathrm{dl})$ for dromedary camels (Abdulkareem et al., 2015b).

The obvious decreasing values of plasma cholesterol concentrations at days 50 and 60 PM as compared with values at days 20 and 30 PM were concomitantly associated with an inverse pattern of plasma progesterone concentrations within similar counterpart periods (Table 1). The cholesterol is a precursor of the most steroid hormones, including progesterone in most ruminant species including camels. High levels of progesterone during pregnancy are always accompanied with decreasing cholesterol concentrations as a result of cholesterol catabolism to progesterone via cholesterol esterase. The hyper-cholesterolemia during pregnancy indicated by approximately $50 \%$ increase over the nopregnant level has been known to influence fetus growth and particularly endocrine function (Sahukar et al., 1986). Lesser values of plasma cholesterol were obtained currently $(6.29-8.86 \mathrm{mg} / \mathrm{dl})$ as compared with normal reference values $(26-52 \mathrm{mg} / \mathrm{dl})$ for dromedary camels (Abdulkareem et al., 2015b). Variations in nutrition plane and season may behind these differences. The highest and lowest values of cholesterol was recorded during winter and summer seasons respectively (El-Harairy et al., 2010).

The overall mean of plasma alkaline phosphatase activity did not alter during the study gestation periods. However, it tended to be greater $(+43.9 \%)$ at day 60 PM (Fig 5). This gradual increasing trend as pregnancy progressed may attributed to increasing placental alkaline phosphatase activity. The alkaline phosphatase normally

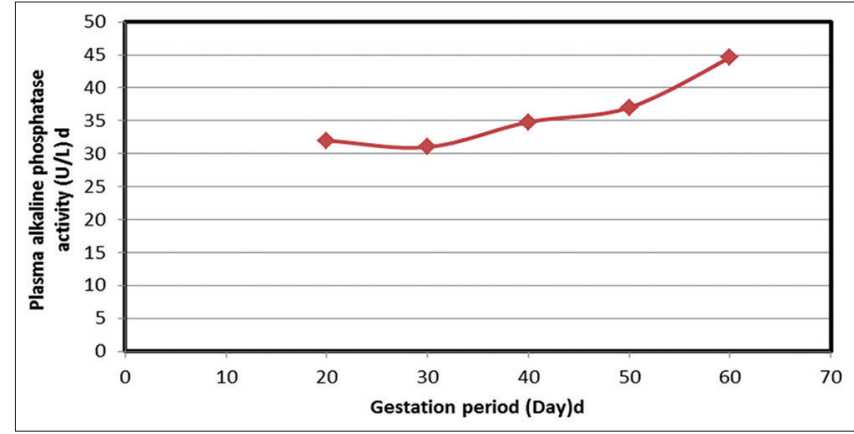

Fig 5. Plasma alkaline phosphatase activity (U/ $L$ ) of Iraqi female camels during different gestation periods.

produced by syncytiotrophoblast cells of placenta and may be involved in migration of primordial germ cell in developing fetus (Heller and Joshi, 2006). In pregnant cows, increases in alkaline phosphatase may be up 4 times normal during mid-pregnancy, playing an important role in fetus musculature via transfer of phosphate (Fernandez and Kidney, 2007). The association between osteogenic differentiation of bone marrow derived mesenchymal stem cells and extracellular alkaline phosphatase activity at early pregnancy (Birmingham et al., 2012) may confirm this notion. On the other hand, the unchanged pattern of alkaline phosphatase activity during PM periods in this study was accompanied by similar trend of plasma estradiol-17 $\beta$ concentrations in their counterpart periods (Table 1). Allcroft and Folley (1941) reported earlier that alkaline phosphatase activity was positively affected by plasma estrogen levels. The lesser activity of plasma alkaline phosphatase was obtained currently $(31-44.6 \mathrm{U} / \mathrm{L})$ as compared with normal reference values $(68-132 \mathrm{U} / \mathrm{L})$ for dromedary camels (Abdulkareem et al., 2015b). Differences in gestation stage, fetus sex, nutrition plane and season may attributed to these result discrepancies. Total and placental alkaline phosphatase levels were higher in pregnant women carrying female fetuses than in male bearing pregnant women (Gol et al., 2006). On the other hand, The lowest value of alkaline phosphatase enzyme was recorded during winter season in dromedary camels (El-Harairy et al., 2010).

\section{CONCLUSION}

In conclusion, the pronounced changes during gestation period in Iraqi dromedary camels can be detected through sex hormones and plasma cholesterol. Plasma progesterone concentrations increased steadily and non-significantly from day 20 PM until day 120 of gestation, whereas, the differences in plasma estradiol-17 $\beta$ concentrations during gestation periods lacked significance. Nonsignificant variations were noticed in plasma glucose concentrations and alkaline phosphatase activity during early gestation periods, while greater plasma cholesterol 
concentrations were observed at days 20 and 30 PM female of dromedary camels. Other studies concerning the profiles of progesterone, estradiol-17 $\beta$ and remaining blood biochemical aspects of Iraqi female dromedary camels during different gestation and post-partum periods are needed to explore the nutritional deficiencies, reproductive metabolic disorders as well as the changes in health status of the dam during these critical periods that may reflect the health status of the neonate.

\section{ACKNOWLEDGMENT}

The authors are grateful to Prof. Dr. Abdul Sattar Faraj Majeed, College of Veterinary Medicine, University of Anbar and Dr. Sajeda Mahdi Eidan, College of Agriculture, University of Baghdad for their technical and consultant assistance.

\section{Authors contribution}

T. A. A. put the experimental design of time of blood sampling as well as the blood biochemical parameters studied. He also responsible for the manuscript writing and assisted in blood analyses. H. M. A. R. has contributed in pregnancy detection of female camels using ultrasonography and rectal palpation. Y. T. A. R. has assisted in blood sampling and analyses of blood biochemical attributes, as well as in pregnancy detection.

\section{REFERENCES}

Abdulkareem, T. A., S. M. Eidan, M. A. Ishak, S. A. M. Al-Sharifi, M. A. Alnimer, C. W. Passavant, J. R. Branen and R. G. Sasser. 2012. Pregnancy-specific protein B (PSPB), progesterone and some biochemical attributes concentrations in the fetal fluids and serum and its relationship with fetal and placental characteristics of Iraqi riverine buffalo (Bubalus bubalis). Anim. Reprod. Sci. 130: 33-41.

Abdulkareem, T. A., H. M. Al-Rawi, Y.T. Abdul-Rahaman and S. M. Eidan. 2015a. Early pregnancy detection of Iraqi female camel (Camelus dromedarius) using different methods. $7^{\text {th }}$ Balkan Animal Science Conference, BALNIMALCON, 3-6 $6^{\text {th }}$ June, Sarajevo, Bosnia and Herzegovina.

Abdulkareem, T. A., S. M. Eidan, A. M. H. Shubber, M. D. Ali and F. F. Ibrahim. 2015b. Normal Physiological Values in Different Animal Species. College of Agriculture, University of Baghdad and Directorate of Animal Resource, Ministry of Agriculture. (In press)

Agarwal, S. P., A. K. Rai and N. D. Khanna. 1992. Hormonal studies in postpartum female camels and their neonates. Theriogenology 38: 735-747.

Al-Eknah, M. M. 2000. Reproduction in old World camels. Anim. Reprod. Sci. 60-61: 583-592.

Al-Eknah, M. M., E. S. E. Gaili and M. H. Sadik. 1997. Studies on indigenous camel breeds in Saudi Arabia. Final report. KACST, Saudi Arabia.

Al-Bisher, B. E. 1998. Pregnancy and parturition in the camel (Camelus dromedarius) with particular reference to cervical dilation. M. V. Sc. Thesis, King Faisal University, Saudi Arabia.

Allain, C. C., L. S. Poon, C. S. G. Chon, W. Richmond and P. Fu. 1974. Enzymatic determination of total serum cholesterol. Clin. Chem. 20: 470-475.

Allcroft, W. M. and S. J. Folley. 1941. Observations on the serum phosphatase of cattle and sheep. J. Biochem. 35: 254-265.

Al-Saiady, M. Y., H. H. Mogawer, S. E. Al-Mutairi, M. Bengoumi, B. Faye, A. Musaad and A. Gar-Elnaby. 2012. Effect of different feeding regime on body weight, ovaries size developments and blood estradiol, progesterone level in pre-pubertal She-camel (Camelus dromedarius). J. Anim. Vet. Adv. 11: 3522-3526.

Ayoub, M. A., A. A. El-Khouly and T. M. Mohamed. 2003. Some hematological and biochemical parameters and steroid hormone levels in the one-humped camel during different physiological conditions. Emir. J. Agric. Sci. 15: 44-55.

Bakheit, S. A., A. M. Faye, C. Majid, A. M. Abu-Nikheila and M. A. Eisa. 2012. Impact of farming system on calving interval of Sudanese camels. In: "Proceedings of the $3^{\text {rd }}$ Conference of the International Society of Camelid Research and Development". $29^{\text {th }}$ Jan-1 ${ }^{\text {st }}$ Feb., Muscat, Sultanate of Oman. pp. 170-171.

Bhakat, C., N. Saini, K. M. L. Pathak and N. V. Patil. 2012. On farm testing of camel management practices in changing agroecological scenario. J. Camel Prac. Res. 19: 45-49.

Birmingham, E., G. L. Niebur, P. E. McHugh, G. Shaw, F. P. Barry and L. M. McNamara. 2012. Osteogenic differentiation of mesenchymal stem cells is regulated by osteocyte osteoblast cells in a simplified bone niche. Eur Cells Mater, 23: 13-27.

Connolly, C. C., L. C. Holste, L. N. Aglione, D. W. Neal, D. B. Lacy, M. S. Smith, M. P. Diamond, A. D. Cherrington and J. L. Chiasson. 2000. Alterations in basal glucose metabolism during late pregnancy in the conscious dog. Am. J. Physiol. Endocrinol. Metab. 279: E1166-E1177.

Deen, A., S. Vyas, M. S. Sahani, P. Saharan, I. Sevta and S. Chabra. 2007. Estradiol-17 $\beta$ and progesterone profiles of female camels at different reproductive stages. Israel J. Vet. Med. 12: 16-48.

Duncan, D. 1955. Multiple range and multiple F-test. Biometrics. 11: 1-24.

El-Harairy, M. A., A. E. B. Zeidan, A. A. Afify, H. A. Amer, and A. M. Amer. 2010. Ovarian activity, biochemical changes and histological status of the dromedary she camel as affected by the different seasons of the year. Nature Sci. 8: 54-65.

Elias, E., E. Bedrak, and R. Yagil. 1984. Estradiol concentration in the serum of the one humped camel (Camelus dromedarius) during the various reproductive stages. Gen. Comp. Endocrinol. 56: 258-264.

El-Tohamy, M. M., A. Salama and A. A. Yousef. 1986. Blood constituents in relation to the reproductive state in she-camel (Camelus dromedarius). Beitr. Trop. Landwirtsch. Veterinarmed. 24: 425-430.

El-Wishy, A. B., N. A. Homeida, M. A. Omar, A. M. Mobarak and A. I. El-Sayed. 1981. Functional changes in the pregnant camel with special reference to fetal growth. Br. Vet. J. 137: 527-537.

Farid, M. F. A. 1995. Nutrient requirements of dromedary camels: Protein and energy requirements for maintenance. J. Arid. Environ. 30: 207-218.

Fernandez, N. J. and B. A. Kidney. 2007. Alkaline phosphatase: beyond the liver. Vet. Clin. Path. 36: 223-233.

Freemark, M., A. Karen, J. Fowlers, T. Mularoni, M. Comer, A. Grandis and L. Kodack. 1992. Placental lactogen receptors in maternal and fetal sheep liver: Regulation by glucose and role in the pathogenesis of fasting during pregnancy. Endocrinology. 130: 1063-1070. 
Gol, M., A. R. Sisman, S. Guclua, S. Altunyurta, B. Onvural and N. Demira. 2006. Fetal gender affects maternal serum total and placental alkaline phosphatase levels during pregnancy. Eur. J. Obst. Gynecol. Reprod. Biol. 128: 253-256.

Hegazy, A. A., A. Ali, M. Al-Eknah and S. Ismail. 2004. Studies on pituitary: Ovarian axis in the female camel with special reference to cystic and inactive ovaries. J. Camel Sci. 1: 16-24.

Heller, D. S. and V. V. Joshi. 2006. Handbook of Placental Pathology. Lippincott Williams \& Wilkins: Philadelphia, USA.

Kind, P. R. N. and E. J. King. 1954. Estimation of plasma phosphatase by determination of hydrolyzed phenol with amino-antipyrine. J. Clin. Pathol. 7: 322-326.

Mohamed, H. E. 2004. The zinc and copper content of the plasma of Sudanese camels (Camelus dromedarius). Vet. Res. Commun. 28: 359-363.

Muhammad, B. F., D. Aliyu, A. A. Njidda and I. L. Madigawa. 2011. Some haematological, biochemical and hormonal profile of pregnant and non-pregnant she-camels (Camelus dromedarius) raised in a Sudan savanna zone of Nigeria. J. Camel Prac. Res. 18: 73-77.

Quzy, I., S. Anwar and G. N. Purohit. 2013. Hormonal management of ovarian activity in breeding camels 2 months ahead of the natural breeding season. Camel Int. J. Vet. Sci. 1: 37-49.

Sahukar, C. S., Pandit, R. K., Chauhan, R. A. S and Porwar, M. L. 1986. Cholesterol and alkaline phosphatase during various reproductive phases in crossbred cows. Indian J. Anim. Sci. 55: 421-423.

SAS. 2012. Statistical Analysis System. User's Guide. Statistical. Version. $9^{\text {th }}$ ed. SAS. Inst. Inc., Cary N.C, USA.
Skidmore, J. A. 2011. Reproductive physiology in female old World camelids. Anim. Reprod. Sci. 124: 148-154.

Skidmore, J. A., W. R. Allen and R. B. Heap. 1994. Oestrogen synthesis by the peri-implantation conceptus of the one-humped camel (Camelus dromedarius). Reprod. Fertil. 101: 363-367.

Skidmore, J. A., M. Billah and W. R. Allen. 1996a. Patterns of hormone secretion throughout pregnancy in the one-humped camel (Camelus dromedarius). Reprod. Fertil. Dev. 8: 863-869.

Skidmore, J. A., F. B. P. Wooding and W. R. Allen. 1996b. Implantation and early placentation in the one-humped camel (Camelus dromedarius). Placenta. 17: 253-262.

Smith, M. F., E. W. Mclntush and G. W. Smith. 1994. Mechanisms associated with corpus luteum development. J. Anim. Sci. 72: 1857-1872.

Sumar, J. B. 2000. Liama and alpacas: In: Hafez, B. and Hafez, E. S. E., Reproduction in Farm Animals. $7^{\text {th }}$ ed. Lippincott Williams and Wilkins, a Wolter Kluwer Co., Philadelphia, U.S.A. pp. 218-236.

Tibary, A. and A. Anouassi. 1997. Theriogenology in Camelidae, Anatomy, Physiology, Pathology and Artificial Breeding. $1^{\text {st }}$ ed Veterinary Research Centre, Ministry of Culture and Information, Abu Dhabi, U.A.E.

Trinder, P. 1969. Determination of glucose in blood using glucose oxidase with an alternative oxygen receptor. Ann. Clin. Biochem. 6: $24-27$

Zhao, X. X. and B.X. Chen. 1995. Peripartal endocrine changes in camels. J. Camel Prac. Res. 2: 123-124.

Zhao, X. X., Y. Zhang, and B. X. Chen. 1998. Serum progesterone and 17 beta estradiol concentrations during pregnancy of Bactrian camel (Camelus bactrianus). Theriogenology. 50: 595-604. 